University of Nebraska - Lincoln

DigitalCommons@University of Nebraska - Lincoln

USGS Staff -- Published Research

US Geological Survey

2007

\title{
Evaluation of Potentially Nonlethal Sampling Methods for Monitoring Mercury Concentrations in Smallmouth Bass (Micropterus dolomieu)
}

Christopher J. Schmitt

U.S.Geological Survey, cjschmitt@usgs.gov

W. G. Brumbaugh

US Geological Survey, Columbia Environmental Research Center, 4200 New Haven Road, Columbia, MO

Follow this and additional works at: http://digitalcommons.unl.edu/usgsstaffpub

Schmitt, Christopher J. and Brumbaugh, W. G., "Evaluation of Potentially Nonlethal Sampling Methods for Monitoring Mercury Concentrations in Smallmouth Bass (Micropterus dolomieu)" (2007). USGS Staff -- Published Research. 881.

http://digitalcommons.unl.edu/usgsstaffpub/881

This Article is brought to you for free and open access by the US Geological Survey at DigitalCommons@University of Nebraska - Lincoln. It has been accepted for inclusion in USGS Staff -- Published Research by an authorized administrator of DigitalCommons@University of Nebraska - Lincoln. 


\title{
Evaluation of Potentially Nonlethal Sampling Methods for Monitoring Mercury Concentrations in Smallmouth Bass (Micropterus dolomieu)
}

\author{
C. J. Schmitt, W. G. Brumbaugh \\ US Geological Survey, Columbia Environmental Research Center, 4200 New Haven Road, Columbia, MO 65201, USA
}

Received: 17 October 2006/Accepted: 17 December 2006

\begin{abstract}
We evaluated three potentially nonlethal alternatives to fillet sampling for the determination of mercury $(\mathrm{Hg})$ concentrations in smallmouth bass (Micropterus dolomieu). Fish ( $n=62,226-464 \mathrm{~mm}$ total length) from six sites in southern Missouri were captured by electrofishing. Blood samples (1 $\mathrm{mL}$ ) from each fish were obtained by caudal veinipuncture with a heparinized needle and syringe. Biopsy needle $(10 \mathrm{~mm} \times 14$ gauge; three cuts per fish; $10-20 \mathrm{mg}$ total dry weight) and biopsy punch $(7 \mathrm{~mm} \times 5 \mathrm{~mm}$ in diameter, one plug per fish, 30-50 mg dry weight) samples were obtained from the area beneath the dorsal fin. Fillet samples were obtained from the opposite side of the fish. All samples were freeze-dried and analyzed for total $\mathrm{Hg}$ by combustion amalgamation atomic absorption spectrophotometry. Mean relative standard deviations (RSDs) of triplicate samples were similar for all four methods $(2.2-2.4 \%)$, but the range of RSDs was greater for blood $(0.4-5.5 \%)$ than for the muscle methods $(1.8-4.0 \%)$. Total $\mathrm{Hg}$ concentrations in muscle were $0.0200-0.8809 \mu \mathrm{g} / \mathrm{g}$ wet weight; concentrations in plug, needle, and fillet samples from each fish were nearly identical. Blood $\mathrm{Hg}$ concentrations were $0.0006-0.0812 \mu \mathrm{g} / \mathrm{mL}$ and were highly correlated with muscle concentrations; linear regressions between log-transformed blood and fillet $\mathrm{Hg}$ concentrations were linear and statistically significant $(p<0.01)$, and explained $91-93 \%$ of the total variation. Correlations between fillet $\mathrm{Hg}$ concentrations and fish size and age were weak; together they explained $\leq 37 \%$ of the total variation, and the relations differed among sites. Overall, any of the alternative methods could provide satisfactory estimates of fillet $\mathrm{Hg}$ in smallmouth bass; however, both blood and plug sampling with disposable instruments were easier to perform than needle sampling. The biopsy needle was the most difficult to use, especially on smaller fish, and its relative expense necessitates reuse and, consequently, thorough cleaning between fish to prevent cross-contamination.
\end{abstract}

Mercury ( $\mathrm{Hg})$ is a natural constituent of the Earth's crust that is released to the environment from natural processes such as

Correspondence to: C. J. Schmitt; email: cjschmitt@usgs.gov volcanic activity and by anthropogenic activities, including fossil fuel combustion, waste incineration, gold mining, disposal of consumer products, and industrial processes (USEPA 2001). Biogeochemical processes can convert inorganic $\mathrm{Hg}$ to methyl mercury $(\mathrm{MeHg})$, which is highly toxic and bioaccumulates and biomagnifies in aquatic ecosystems (Neumann and Ward 1999; Wiener et al. 2002). MeHg is therefore widely recognized as a threat to wildlife and human health (Wiener et al. 2002), and nationwide $\mathrm{Hg}$-based advisories and criteria for the protection of wildlife and humans have been developed (USEPA 2000, 2004). Many states have issued additional advisories; Missouri recommends that sensitive populations (pregnant women, women of childbearing age, nursing mothers, and children $<13$ years old) consume not more than one meal per month of largemouth bass (Micropterus salmoides) or smallmouth bass (Micropterus dolomieu) of $\geq 12$ in. (305 mm) total length (TL) (MDHSS 2006).

We investigated $\mathrm{Hg}$ in smallmouth bass from the Eleven Point, Current, and Jacks Fork Rivers of southeastern Missouri (Fig. 1). These rivers derive much of their flow from groundwater, and their watersheds are sparsely populated, mostly forested, and contain few point-sources of contamination (Miller and Wilkerson 2000; Petersen et al. 1998). The upper Current River and most of the Jacks Fork are within the Ozark National Scenic Riverways (ONSR), a national park; and much of the Eleven Point in Missouri is part of the National Wild and Scenic Rivers system. As such, the rivers represent nationally significant natural resources that are heavily used for a variety of recreational activities, including sport fishing; smallmouth bass are among the most frequently sought species. Human consumption of smallmouth bass is permitted subject to the statewide minimum size of $305 \mathrm{~mm}$ TL. The Current River and Jacks Fork also support populations of Ozark hellbender (Cryptobranchus bishopi), a large, predatory salamander that is considered endangered in Missouri and that has been proposed for federal listing (MDC 2006). We also sampled the Big River, which has been contaminated by tailings from historical lead-zinc mining (Gale et al. 2004) and where a consumption advisory due to elevated lead concentrations in bottom-dwelling fish has been issued (MDHSS 2006). Although elevated $\mathrm{Hg}$ concentrations have not been reported, the Big River downstream of where we sampled is 


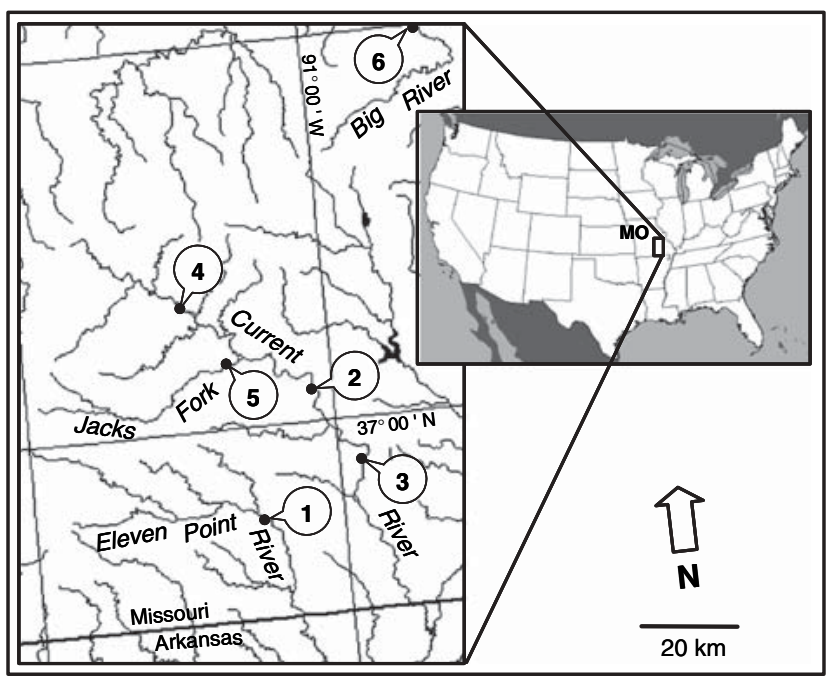

Fig. 1. Collection sites in southeastern Missouri, USA

managed for trophy smallmouth bass; the daily limit is one fish $\geq 15$ in. (381 mm) TL (Menau 1997), which increases the potential for elevated $\mathrm{Hg}$ concentrations.

Monitoring for $\mathrm{Hg}$ and other contaminants in fish as presently conducted in Missouri and elsewhere requires the periodic killing of game species to obtain fillet samples, a practice that is becoming increasingly unpopular among natural resource management agencies and their constituents. It is also not appropriate for threatened or endangered species. Studies conducted elsewhere have demonstrated the utility of muscle biopsy sampling as an alternative to sampling fillets or whole fish for $\mathrm{Hg}$ monitoring (Baker et al. 2004; Cizdziel et al. 2002a, 2003; Peterson et al. 2002, 2005; Uthe 1971) and selenium (Hamilton et al. 2004; Waddell and May 1995) and for obtaining samples for genetic analyses (Crawford et al. 1977; Leitner and Isely 1994). The analysis of scales (Lake et al. 2006) and caudal fin tissue (Gremillion et al. 2005) have also been evaluated for $\mathrm{Hg}$. Blood sampling represents a feasible alternative for monitoring $\mathrm{Hg}$ in wildlife (Franson et al. 1999) and humans (Hightower and Moore 2003) and for lead and cadmium in fish (Brumbaugh et al. 2005), but it has received only limited investigation for $\mathrm{Hg}$ in fish (e.g., Cizdziel et al. 2003). Blood sampling for $\mathrm{Hg}$ in small animals was historically hindered by the difficulty of collecting sufficient volumes relative to available analytical sensitivity, especially for multicontaminant investigations; blood concentrations of some metals are low compared to typical "target organs" or tissues (e.g., liver or kidney, muscle, or whole fish). The recent maturation and US Environmental Protection Agency (EPA) approval of combustion-amalgamation atomic absorption spectrophotometry (CA-AAS; USEPA method 7473) for $\mathrm{Hg}$ determination, together with improvements in ultratrace field and laboratory procedures, have facilitated the routine measurement of $\mathrm{Hg}$ at low concentrations in small-volume samples.

Our primary objective was to evaluate three potentially nonlethal alternatives to fillet sampling for $\mathrm{Hg}$ in smallmouth bass. These included samples of muscle tissue obtained via biopsy punch and biopsy needle and blood samples obtained with a needle and syringe. All samples were analyzed for total
$\mathrm{Hg}$ by CA-AAS. We also evaluated improvements in the accuracy and precision of estimated fillet concentrations that resulted from including the length, weight, and age of the fish in statistical models. Secondary objectives were to provide contemporary data on $\mathrm{Hg}$ concentrations in Missouri smallmouth bass and to evaluate the data relative to current guidelines for human consumption (MDHSS 2006; USEPA 2000, 2004). We also offer suggestions for future $\mathrm{Hg}$ monitoring and research.

\section{Materials and Methods}

The procedures described here conform to the recommendations of the American Society of Ichthyologists and Herpetologists (ASIH), American Fisheries Society (AFS), and American Institute of Fishery Research Biologists (AIFRB) (ASIH, ASF, AIFRB 2004) and with all guidelines for the humane treatment of test organisms during culture and experimentation of the US Geological Survey and our laboratory. The study was conducted in accordance with a Wildlife Collector's Permit issued by the MDC and a Scientific Investigator Permit from the US National Park Service (NPS).

\section{Sample Containers and Cleaning Procedures}

Blood and biopsy samples were stored in $1.8-\mathrm{mL}$ polyethylene cryogenic vials (Nunc ${ }^{\circledR} 347627$, Nalge-Nunc International, Naperville, IL). The vials and caps were submerged overnight in a bath of $4 \mathrm{M}$ nitric acid and $2 \mathrm{M}$ hydrochloric acid, followed by overnight soaking in deionized water. They were then triple-rinsed with highpurity deionized water $(>15 \mathrm{M} \Omega / \mathrm{cm})$ and dried in a HEPA-filtered air oven, capped, and stored in a zipper-seal polyethylene bag. Aluminum foil squares $(5 \times 5 \mathrm{~cm})$ for dissecting plug samples were precleaned by overnight immersion in methanol and air-drying in a fume hood. They were also stored in a zipper-seal polyethylene bag. Fillet samples were stored in 1-qt zipper-seal polyethylene freezer storage bags; the bags were not precleaned. Samples were processed and handled with stainless-steel instruments (forceps, scalpel, fillet knife, biopsy needle) that were washed in laboratory detergent and rinsed with tap water and methanol between fish to prevent cross-contamination.

\section{Field Procedures}

Smallmouth bass were collected by electrofishing from sites on the Eleven Point, Current, Jacks Fork, and Big rivers from late August to early October 2005 (Fig. 1; Table 1). The nominal collection target was 12 fish of a size range representative of what might be caught by anglers (200-500 $\mathrm{mm}$ TL) at each site. A wide range (i.e., including fish $<305 \mathrm{~mm}$ TL) was sought from each site to facilitate the development and evaluation of regression models because $\mathrm{Hg}$ concentrations in predatory species tend to increase with fish size and age (Neumann and Ward 1999; Peles et al. 2006; Wiener et al. 2002).

Fish were held in situ in mesh cages for $\leq 4 \mathrm{~h}$ after capture. They were processed according to a protocol modified from Waddell and May (1995), Brumbaugh et al. (2001, 2005), Cizdziel et al. (2002a), Schmitt et al. (1999), and Baker et al. (2004) that was designed to minimize contact between the samples and the mucus coating and external surfaces of the fish, which represent potential sources of contamination (Schmitt and Finger 1987). Each fish was placed on a measuring board covered with a clear polyethylene bag turned inside- 
Table 1. Fish collection sites in southern Missouri, USA and sampling dates

\begin{tabular}{|c|c|c|c|c|c|}
\hline Site & River & Location & County & Latitude, longitude $^{\text {a }}$ & Date \\
\hline 1 & Eleven Point & Turner's Mill & Oregon & $36^{\circ} 45^{\prime} 56.7^{\prime \prime} \mathrm{N}, 91^{\circ} 16^{\prime} 01.0^{\prime \prime} \mathrm{W}$ & $08-29-2005$ \\
\hline 2 & Current & Cataract Landing & Carter & $36^{\circ} 53^{\prime} 22.2^{\prime \prime} \mathrm{N}, 90^{\circ} 54^{\prime} 47.3^{\prime \prime} \mathrm{W}$ & 08-30-2005 \\
\hline 3 & Current & Waymeyer Landing & Carter & $37^{\circ} 03^{\prime} 03.2^{\prime \prime} \mathrm{N}, 91^{\circ} 03^{\prime} 16.8^{\prime \prime} \mathrm{W}$ & 08-31-2005 \\
\hline 4 & Current & Presley Center & Shannon & $37^{\circ} 19^{\prime} 12.6^{\prime \prime} \mathrm{N}, 91^{\circ} 26^{\prime} 14.6^{\prime \prime} \mathrm{W}$ & 09-07-2005 \\
\hline 5 & Jacks Fork & Shawnee Creek & Shannon & $37^{\circ} 10^{\prime} 21.3^{\prime \prime} \mathrm{N}, 91^{\circ} 18^{\prime} 00.6^{\prime \prime} \mathrm{W}$ & 09-08-2005 \\
\hline 6 & Big & St. Francois State Park & St. Francois & $37^{\circ} 57^{\prime} 23.7^{\prime \prime} \mathrm{N}, 90^{\circ} 32^{\prime} 29.2^{\prime \prime} \mathrm{W}$ & $10-04-2005$ \\
\hline
\end{tabular}

${ }^{\text {a }}$ As documented by global positioning system receiver $( \pm<10 \mathrm{~m})$, datum = World Geodetic System 1984 (WGS 84).

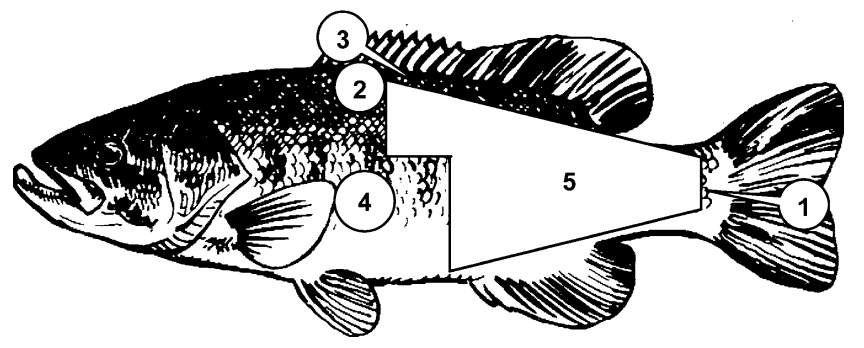

Fig. 2. Approximate locations on the fish from which samples were obtained: (1) blood; (2) plug; (3) needle; (4) scales; (5) fillet (from the opposite side). Also shown for (1) and (3) are the instrument insertion points and trajectories. Image source: US Fish and Wildlife Service (http://images.fws.gov). After Cizdziel et al. (2002a)

out. Blood (nominally $1 \mathrm{~mL}$ ) was obtained by caudal veinipuncture using a chilled, heparinized $(6 \mathrm{IU} / \mathrm{mL})$ disposable needle and syringe (Fig. 2) and dispensed into a polyethylene vial. The fish was then killed with a blow to the head, weighed (g), and measured (TL, mm). Scales were removed from the area beneath the dorsal fin on the left side of the fish. A tissue plug sample was obtained from this area with a 7-mm $\times 5$-mm (diameter) disposable biopsy punch (Uni-Punch ${ }^{\circledR}$, Premier Medical, Plymouth Meeting, PA; Fig. 2), as recommended by Cizdziel et al. (2002a). The plug was extracted with forceps and placed on a foil square, the skin was cut from the exterior surface with a scalpel, and the sample was transferred to a polyethylene vial. Needle samples were then obtained from the area beneath the posterior dorsal fin with a 6-in $\times 14$-g $\left(10-\mathrm{mm}\right.$ specimen notch) TruCut ${ }^{\circledR}$ sheathed stainless-steel biopsy needle (Allegiance, McGaw Park, IL) and transferred to a polyethylene vial without skin. Each needle sample represented (nominally) three cuts with the instrument through the dorsal musculature near the mid-sagittal plane of the fish, with the instrument oriented postero-ventrally (Fig. 2); additional cuts were made if the specimen notch was not full. A scale sample was removed from near the left pectoral fin (Fig. 2) for age determination (Jearld 1983). A skinless fillet was obtained with a knife from the area dorsal and posterior to the abdominal cavity on the opposite (right) side of the fish (Fig. 2) and placed in a polyethylene bag. The gender of the fish was determined by internal observation. All muscle and blood samples were frozen in dry ice immediately after collection. Upon return to the laboratory, the blood and muscle samples were transferred to a freezer $\left(-20^{\circ} \mathrm{C}\right)$ until thawed for analytical processing.

As part of the quality assurance (QA) program, triplicate samples were prepared from one large fish $(>400 \mathrm{~mm}$ TL) from each of sites 1-5 to evaluate repeatability; no large fish were obtained at site 6 . Three plug samples, three needle samples (each representing at least three needle cuts), and three blood samples of $1-1.5 \mathrm{~mL}$ from a single syringe containing $3-5 \mathrm{~mL}$ of blood were obtained from each of these fish and placed in separate containers. Triplicate fillet samples were prepared in the laboratory as the samples were processed. Between fish preparations, all contact surfaces were thoroughly cleaned with tap water, the biopsy needle and all dissecting instruments were cleaned, and the polyethylene bag on which the fish had been dissected was replaced. Disposable items (biopsy punch, needle and syringe) were used for only one fish, and a new biopsy needle was used for each site.

\section{Laboratory Methods and Quality Assurance}

All samples were freeze-dried before analysis. The moisture content of blood and fillet samples was determined based on weight loss during lyophylization. Fillet samples were rinsed twice in their zipperseal bag with high-purity deionized water, drained thoroughly, and transferred to a preweighed glass dish in which they were chopped into $2-\mathrm{cm}^{2}$ pieces, weighed, and freeze-dried. For blood, a $0.1-0.2-\mathrm{mL}$ subsample was pipetted into a preweighed vial and weighed prior to lyophilization. The moisture content of plug and needle samples was not determined due to the small sample mass. Prior to analysis, dried fillet samples were transferred to a heavy-duty zipper-seal polyethylene bag in which they were pulverized and hand-mixed to produce a uniform, fibrous powder. Dried blood samples were crushed to a fine powder with a microspatula just before analysis. Dried needle and plug samples received no further processing. Total $\mathrm{Hg}$ concentrations in the dried samples were determined by CA-AAS with a Milestone DMA-80 direct $\mathrm{Hg}$ analzyer (Milestone Inc., Shelton, CT). Instrument calibration was performed with approximately $20,40,60$, and $100 \mathrm{mg}$ of three different freeze-dried, certified reference fish tissues representing a wide range of $\mathrm{Hg}$ masses (5-400 ng). Dry-weight (dw) concentrations were converted to wet-weight (ww) values using the individually determined moisture content of the blood and fillet samples; fillet moisture content was used to convert the needle and plug values.

In addition to the field triplicates and instrument calibration standards, laboratory QA measures included the analysis of analytical replicates, blanks, fortified (spiked) samples, and certified reference materials. Samples were analyzed in groups of 20-25 on 12 analysis days (3 runs each for blood, plug, biopsy needle, and fillet samples). Sample types were alternated over the 12 runs to neutralize bias associated with slight day-to-day changes in instrument baseline and response. Three blanks, at least three certified reference tissues, a sample triplicate, and at least two sample spikes were distributed among the samples in each run. Recovery of MeHg sample spikes $(n=24)$ was $104-114 \%$ (mean $=109 \%)$; results were not adjusted for recovery efficiency. One low-concentration and one high-concentration certified reference tissue were analyzed before and after each run to confirm the accuracy of the low and high DMA- 80 calibration curves (long and short cell paths). Standard reference materials included tissue samples from the National Institute of Standards and Technology (NIST), the National Research Council of Canada (NRCC), and the International Atomic Energy Association (IAEA). The mean concentrations for all analyses of these matrixes were within certified ranges except for bovine blood, which was slightly lower than the certified concentration; however, only three bovine blood samples were analyzed (Table 2). 
Table 2. Results of analyses of certified reference materials for total mercury (all $\mu \mathrm{g} / \mathrm{g} \mathrm{dw}$ )

\begin{tabular}{lllrr}
\hline Reference ID & Supplier & Matrix & Certified range & \multicolumn{1}{c}{$\begin{array}{l}\text { Measured concentrations } \\
\text { (mean } \pm 1 \text { SD) }\end{array}$} \\
\hline RM50 & & & & $0.93 \pm 0.02$ \\
DORM-2 & NIST & Albacore tuna fillet & $0.95 \pm 0.10$ & $4.56 \pm 0.14$ \\
DOLT-2 & NRCC & Dogfish muscle & $4.64 \pm 0.26$ & $2.30 \pm 0.04$ \\
CRM-407 & NRCC & Dogfish liver & $2.14 \pm 0.28$ & $0.216 \pm 0.003$ \\
SRM 2976 & IAEA & Whole fish & $0.222 \pm 0.006$ & $0.058 \pm 0.003$ \\
SRM 107b & NIST & Mussel tissue & $0.0610 \pm 0.0036$ & $0.136 \pm 0.005$ \\
\hline
\end{tabular}

Blank-equivalent total $\mathrm{Hg}$ concentrations for analyses of blood, plug, and fillet samples were $<0.0001-0.0016 \mu \mathrm{g} / \mathrm{g} \mathrm{dw}$ (mean $=0.0009 \mu \mathrm{g} / \mathrm{g} \mathrm{dw}, n=27$ ) assuming a sample analysis mass of $50 \mathrm{mg} \mathrm{dw}$; they were $0.007-0.017 \mu \mathrm{g} / \mathrm{g} \mathrm{dw}$ (mean $=0.012 \mu \mathrm{g} / \mathrm{g} \mathrm{dw}$, $n=9$ ) for needle samples assuming an analysis mass of $15 \mathrm{mg} \mathrm{dw}$. The method limits of detection (LODs) were calculated for each run by multiplying the pooled standard deviation (SD) of blank-equivalent concentrations and a triplicate analysis of a low-concentration sample by 3.3 . The LODs were $0.001-0.010 \mu \mathrm{g} / \mathrm{g}$ dw (mean $=0.006 \mu \mathrm{g} / \mathrm{g}$ $\mathrm{dw}, n=9$ ) for blood, plug, and fillet samples and 0.006-0.037 $\mu \mathrm{g} / \mathrm{g}$ $\mathrm{dw}($ mean $=0.023 \mu \mathrm{g} / \mathrm{g} \mathrm{dw}, n=3$ ) for needle samples. Depending on moisture content, these represent approximate LODs of 0.0012 0.0014 (mean $=0.0013) \mu \mathrm{g} / \mathrm{g}$ ww for fillet and plug samples, 0.0006 $0.0012($ mean $=0.0009) \mu \mathrm{g} / \mathrm{mL}$ for blood samples, and 0.0048 0.0055 (mean $=0.0013) \mu \mathrm{g} / \mathrm{g}$ ww for needle samples. The instrument detection limit (IDL) was $\sim 0.05 \mathrm{ng}(0.00005 \mu \mathrm{g})$, or about $0.001 \mu \mathrm{g} / \mathrm{g}$ $\mathrm{dw}$, as a sample-equivalent concentration assuming a 50-mg analysis mass. The relative standard deviation (RSD) of within-run analytical (instrument) triplicates $(n=12)$ was $0.4-7.0 \%$ (mean $=2.5 \%$ ). Mean RSDs for the field-collected triplicates ( $n=5$ of each matrix) were similar for all four methods $(2.2-2.4 \%)$, but the range of RSDs was slightly greater for blood $(0.4-5.5 \%)$ than for the fillet, needle and plug samples $(1.8-4.0 \%)$. Based on the latter results, which indicated a high degree of repeatability for all four sample types, the arithmetic mean of the triplicate analyses was reported for these fish.

A sample of the sodium heparin salt and four $0.2-\mathrm{mL}$ heparin needle/syringe rinse solutions (each transferred to the analyzer with a separate needle and syringe) were analyzed for $\mathrm{Hg}$ to check for possible contamination of blood samples during collection. The $\mathrm{Hg}$ concentration in the heparin salt was $0.002 \mu \mathrm{g} / \mathrm{g}$ dw (twice the IDL) and was below the IDL in all four needle/syringe rinses, indicating that contamination was negligible.

\section{Dataset Composition and Statistical Analyses}

Samples representing 62 smallmouth bass were obtained; the target of 12 fish was obtained from sites 1-3 and 5, but only 11 were obtained from site 4, and site 6 yielded only three. Fish were 226-467 mm TL, weighed $144-1330 \mathrm{~g}$, and were 2-6 years old. Only regenerated scales were obtained from one fish from site 1 , and it could not be aged. Data from this fish were excluded from all analyses involving age. A single $\log -\log$ regression of weight against TL accounted for $98 \%$ of the variation; the relationship was similar across all sites and genders, and no sites deviated appreciably from the general trend of the data.

Analysis of variance (ANOVA), analysis of covariance (ANCOVA), and multiple linear regression were used to test for differences among sites, genders, and the interactions of these factors and to evaluate the effects of TL, weight, and age on $\mathrm{Hg}$ concentrations. We also tested TL-, weight-, and age-adjusted $\mathrm{Hg}$ fillet concentrations ( $\mathrm{HgTL}, \mathrm{HgWt}$, and $\mathrm{HgA}$, respectively), computed as described by Brumbaugh et al. (2001) and Neumann and Ward (1999). Proc GLM and Proc REG of the Statistical Analysis System, Version 9.1 (SAS
Institute, Carey, NC) were used for these analyses. The Type-II sums of squares, which test for the significance of individual variables after accounting for all other variables in the model, were evaluated. Summary statistics comparing the measured versus predicted concentrations were computed for each method and model. Most values representing $\mathrm{Hg}$ concentrations, $\mathrm{TL}$, and weight were $\log _{10}$-transformed prior to analysis; percent moisture was transformed using the angular transformation. Arithmetic means and standard errors are presented and discussed, but all statistical tests were based on transformed least squares means, which are adjusted for all factors in the ANOVA model and are therefore unbiased with respect to sample size. A nominal $p$-value of $\alpha=0.05$ was used to judge statistical significance unless otherwise indicated.

\section{Results}

\section{Moisture Content}

Fillet moisture content was consistent (76.3-79.7\%, mean $=78.5 \%$ ) and did not differ significantly among sites or genders (ANOVA, $p>0.05$ ). Blood moisture was less consistent $(79.5-89.2 \%$, mean $=84.1 \%)$ but also did not differ significantly among sites or genders. This variation probably reflected the small volume of blood used for the moisture determinations.

\section{Mercury in Muscle Tissue}

Results of the statistical analyses of $\mathrm{dw}$ and ww Hg concentrations were nearly identical due to the relatively uniform moisture content of the samples. Therefore, we focus primarily on the ww results, which are more directly applicable for risk analysis.

Mercury was detected in all fillet samples at concentrations of $0.0200-0.8809 \mu \mathrm{g} / \mathrm{g}$ ww $(0.091-4.123 \mu \mathrm{g} / \mathrm{g} \mathrm{dw})$. The lowest concentrations, which were in fish from site 6 , exceeded the LOD $(0.006 \mu \mathrm{g} / \mathrm{g} \mathrm{dw})$ by 15 -fold. Measured concentrations and TL-, weight-, and age-adjusted concentrations differed significantly among sites, but not among genders, and were generally lowest at site 6 and highest at site 4 (Table 3). The rank order of the means for sites 1-3 and 5 differed slightly relative to the unadjusted concentrations, but differences between the means for these sites were small (Table 3). The ANOVA based on age-adjusted concentrations explained a greater amount of the total variation $(80 \%)$ than the measured concentrations, TL-adjusted concentrations, or weight-adjusted values (Table 3). Fillet concentrations generally in- 
Table 3. $\mathrm{Mean}^{\mathrm{a}} \pm$ standard error concentrations (all wet weight) of $\mathrm{Hg}$, length-adjusted $\mathrm{Hg}(\mathrm{HgTL})$, weight-adjusted $\mathrm{Hg}(\mathrm{Hg} / \mathrm{Wt}$ ), and ageadjusted $\mathrm{Hg}(\mathrm{HgA})$ in fillets and of $\mathrm{Hg}$ in blood $(\mathrm{HgB})$ of female $(\mathrm{F})$, juvenile $(\mathrm{J})$, and male $(\mathrm{M})$ smallmouth bass from six sites

\begin{tabular}{|c|c|c|c|c|c|c|c|}
\hline Site & Sex & $n$ & $\mathrm{Hg}(\mu \mathrm{g} / \mathrm{g})$ & $\operatorname{HgTL}(\mu \mathrm{g} / \mathrm{g} / \mathrm{m})$ & $\mathrm{HgWt}(\mu \mathrm{g} / \mathrm{g} / \mathrm{kg})$ & $\mathrm{HgA}(\mu \mathrm{g} / \mathrm{g} / \mathrm{y})$ & $\mathrm{HgB}(\mu \mathrm{g} / \mathrm{mL})$ \\
\hline \multirow[t]{4}{*}{1} & All & $3^{\mathrm{b}}$ & $0.2604 \pm 0.0265$ & $0.838 \pm 0.062$ & $0.674 \pm 0.089$ & $0.065 \pm 0.006$ & $0.0127 \pm 0.0022$ \\
\hline & $\mathrm{F}$ & 4 & $0.2638 \pm 0.0439$ & $0.778 \pm 0.112$ & $0.508 \pm 0.117$ & $0.071 \pm 0.019$ & $0.0096 \pm 0.0008$ \\
\hline & $\mathrm{J}$ & 2 & $0.2129 \pm 0.0138$ & $0.773 \pm 0.098$ & $0.812 \pm 0.132$ & $0.053 \pm 0.003$ & $0.0117 \pm 0.0018$ \\
\hline & M & 6 & $0.3046 \pm 0.0233$ & $0.961 \pm 0.072$ & $0.703 \pm 0.118$ & $0.069 \pm 0.007$ & $0.0169 \pm 0.0013$ \\
\hline \multirow[t]{4}{*}{2} & All & $3^{\mathrm{b}}$ & $0.3775 \pm 0.0423$ & $1.204 \pm 0.060$ & $1.103 \pm 0.122$ & $0.095 \pm 0.002$ & $0.0197 \pm 0.0042$ \\
\hline & $\mathrm{F}$ & 6 & $0.4357 \pm 0.0833$ & $1.301 \pm 0.244$ & $1.025 \pm 0.192$ & $0.096 \pm 0.014$ & $0.0244 \pm 0.0064$ \\
\hline & $\mathrm{J}$ & 1 & 0.2953 & 1.094 & 1.342 & 0.098 & 0.0113 \\
\hline & $\mathrm{M}$ & 5 & $0.4015 \pm 0.0477$ & $1.219 \pm 0.111$ & $0.944 \pm 0.075$ & $0.091 \pm 0.008$ & $0.0234 \pm 0.0051$ \\
\hline \multirow[t]{4}{*}{3} & All & $3^{\mathrm{b}}$ & $0.2907 \pm 0.0253$ & $0.995 \pm 0.091$ & $1.168 \pm 0.246(2)$ & $0.082 \pm 0.010$ & $0.0129 \pm 0.0037$ \\
\hline & $\mathrm{F}$ & 8 & $0.3353 \pm 0.0800$ & $1.041 \pm 0.146$ & $1.007 \pm 0.175$ & $0.086 \pm 0.012$ & $0.0203 \pm .0086$ \\
\hline & $\mathrm{J}$ & 1 & 0.2891 & 1.125 & 1.652 & 0.096 & 0.0085 \\
\hline & M & 3 & $0.2476 \pm 0.0280$ & $0.819 \pm 0.122$ & $0.847 \pm 0.178$ & $0.063 \pm 0.007$ & $0.0099 \pm 0.0012$ \\
\hline \multirow[t]{3}{*}{4} & All & $2^{\mathrm{b}}$ & $0.4454 \pm 0.0090$ & $1.472 \pm 0.071$ & $1.278 \pm 0.227$ & $0.111 \pm 0.001$ & $0.0275 \pm 0.0001$ \\
\hline & $\mathrm{F}$ & 5 & $0.4364 \pm 0.0945$ & $1.543 \pm 0.295$ & $1.505 \pm 0.277$ & $0.109 \pm 0.013$ & $0.0275 \pm 0.0094$ \\
\hline & $\mathrm{M}$ & 6 & $0.4544 \pm 0.0806$ & $1.402 \pm 0.219$ & $1.051 \pm 0.160$ & $0.111 \pm 0.015$ & $0.0276 \pm 0.0057$ \\
\hline \multirow[t]{4}{*}{5} & All & $3^{\mathrm{b}}$ & $0.2318 \pm 0.0273$ & $0.898 \pm 0.079$ & $1.106 \pm 0.185$ & $0.082 \pm 0.010$ & $0.0116 \pm 0.0005$ \\
\hline & $\mathrm{F}$ & 10 & $0.2865 \pm 0.0195$ & $1.032 \pm 0.060$ & $1.126 \pm 0.124$ & $0.075 \pm 0.004$ & $0.0244 \pm 0.0203$ \\
\hline & $\mathrm{J}$ & 1 & 0.2040 & 0.903 & 1.417 & 0.102 & 0.0113 \\
\hline & M & 1 & 0.2050 & 0.759 & 0.777 & 0.068 & 0.0109 \\
\hline 6 & $\mathrm{~F}$ & 3 & $0.0279 \pm 0.0079$ & $0.105 \pm 0.030$ & $0.120 \pm 0.044(6)$ & $0.008 \pm<0.001$ & $0.0009 \pm 0.0001$ \\
\hline All & All & 62 & $0.2723 \pm 0.0212$ & $0.919 \pm 0.059$ & $0.908 \pm 0.060$ & $0.082 \pm 0.004$ & $0.0142 \pm 0.0018$ \\
\hline \multicolumn{8}{|l|}{ ANOVA } \\
\hline Site & $5,47^{\mathrm{c}}$ & $25.18 * *$ & $31.78^{* *}$ & $16.11 * *$ & $36.61 * *$ & $20.37 * *$ & \\
\hline Sex & $2,47^{\mathrm{c}}$ & 0.51 & 0.18 & 2.20 & 0.50 & 0.57 & \\
\hline Site $\times$ Sex & $7,47^{\mathrm{c}}$ & 0.30 & 0.14 & 0.55 & 0.59 & 0.75 & \\
\hline$R^{2}$ & 61 & 0.75 & 0.78 & 0.66 & 0.80 & 0.72 & \\
\hline
\end{tabular}

Numbers in parentheses indicate rank orders of site means (1-6, highest to lowest). Also shown are results of analysis of variance (ANOVA), as $F$-values $(* * p<0.01)$, degrees of freedom, and coefficients of determination $\left(R^{2}\right)$, evaluating the effects of site and sex on $\mathrm{Hg}$ concentrations.

${ }^{\mathrm{a}}$ Unweighted arithmetic means and standard errors; all data $\log _{10}$-transformed for ANOVA.

${ }^{\mathrm{b}}$ Number of means.

${ }^{\mathrm{c}}$ Degrees of freedom.

creased with age; differences among sites and ages were statistically significant $(p<0.01$; Table 4$)$. However, significant Site $\times$ Age interaction indicated that the increase was not uniform; at some sites, the concentrations were higher in 2- or 3 -year-old fish than in older individuals (Table 4). Site and age together accounted for $93 \%$ of the variation in fillet $\mathrm{Hg}$ (Table 4).

Mercury concentrations in needle and plug samples were nearly identical to those in fillet samples from the same fish (Fig. 3). One needle sample representing a fish from site 2 was compromised during preparation. The lowest measured concentration in needle samples $(0.522 \mu \mathrm{g} / \mathrm{g} \mathrm{dw}, 0.1201 \mu \mathrm{g} / \mathrm{g}$ ww) exceeded the LOD $(0.023 \mu \mathrm{g} / \mathrm{g} \mathrm{dw})$ by 23 -fold. Needle samples were not obtained from site 6, where fillet $\mathrm{Hg}$ concentrations were as low as $0.091 \mu \mathrm{g} / \mathrm{g} \mathrm{dw}(0.0200 \mu \mathrm{g} / \mathrm{g}$ ww). If measured, these concentrations would have exceeded the needle LOD by fourfold. Averaged over all fish from which fillet, plug, and needle samples were obtained $(n=59$, sites 1-5), plug and needle $\mathrm{Hg}$ values differed from the corresponding fillet values by $\leq 4.1 \%$, and $78 \%$ of the needle values, and $83 \%$ of the plug values differed by $<5 \%$. However, the range of deviations was large (Table 5). Inspection of the data indicated that these ranges were caused by one divergent biopsy sample of each type (Fig. 3). One plug concentration was only $54 \%$ of the corresponding fillet and needle values, which were nearly identical (mean $=0.3485 \mu \mathrm{g} / \mathrm{g}$ ); and one needle value was only about
$68 \%$ of the corresponding fillet and plug values, which were also nearly identical $($ mean $=0.1755 \mu \mathrm{g} / \mathrm{g}$ ). The reasons for these deviations could not be determined but might have included instrument malfunction, operator error, or both. Without these extremes, the mean deviations were $\leq 3.4 \%$ for both biopsy methods (Table 5). Simple linear regressions between fillet $\mathrm{Hg}$ and needle or plug $\mathrm{Hg}$ were statistically significant, had intercepts near zero and slopes near 1.0 and explained $98-99 \%$ of the variation in fillet $\mathrm{Hg}$ (Fig. 3). No statistically significant improvements in these models could be achieved by fitting additional variables (TL, weightt, age) using multiple linear regression.

\section{Mercury in Blood}

Mercury was also detected in all blood samples at concentrations of $0.0006-0.0812 \mu \mathrm{g} / \mathrm{mL}(0.004-0.418 \mu \mathrm{g} / \mathrm{g} \mathrm{dw})$, which were $\leq 10 \%$ of the corresponding muscle concentrations (Table 3). The lowest concentrations in blood $(0.004$ $0.006 \mu \mathrm{g} / \mathrm{g} \mathrm{dw}, 0.0006-0.0011 \mu \mathrm{g} / \mathrm{mL}$; all from site 6) were barely detectable at the nominal LOD $(0.006 \mu \mathrm{g} / \mathrm{g} \mathrm{dw})$. Trends mirrored those of the fillet concentrations; differences among sites, but not genders, were statistically significant, and the rank order of the site means was identical to that of the unadjusted fillet concentrations (Table 3). 
Table 4. Mean \pm standard error concentrations of mercury $(\mu \mathrm{g} / \mathrm{g}$, ww) in fillet samples $(n=61)$ from smallmouth bass of the indicated age $(y)$ from six sites

\begin{tabular}{|c|c|c|c|c|c|}
\hline Site & II & III & IV & $\mathrm{V}$ & VI age (y) \\
\hline 1 & - & - & $0.2698 \pm 0.0241$ & $0.2392 \pm 0.0667$ & $0.3067(1)$ \\
\hline 2 & - & $0.2369 \pm 0.0306$ & $0.4172 \pm 0.0735$ & $0.4902 \pm 0.0552$ & $0.5333 \pm 0.1457$ \\
\hline 3 & - & $0.2708 \pm 0.0215$ & $0.2264 \pm 0.0176$ & $0.3030(1)$ & 0.8809 \\
\hline 4 & - & $0.2341 \pm 0.0078$ & $0.5215 \pm 0.0470$ & $0.7532(1)$ & $0.6112(1)$ \\
\hline 5 & $0.2040(1)$ & $0.2443 \pm 0.0158$ & $0.2801 \pm 0.0342$ & $0.3476(1)$ & $0.3808(1)$ \\
\hline 6 & - & $0.0201 \pm 0.0001$ & 0.0436 & - & - \\
\hline \multicolumn{6}{|l|}{ ANOVA } \\
\hline Site & $59.89_{5,39} * *$ & & & & \\
\hline Age & $19.42_{4,39} * *$ & & & & \\
\hline Site $\times$ Age & $3.8612,39 *$ & & & & \\
\hline$R^{2}$ & 0.93 & & & & \\
\hline
\end{tabular}

Note. Also shown are the results of ANOVA, as $F$-values $(* p<0.05 ; * *<0.01)$, degrees of freedom, coefficients of determination $\left(R^{2}\right)$, and $n$, evaluating the effects of site and age. Roman numbers represent age(y).

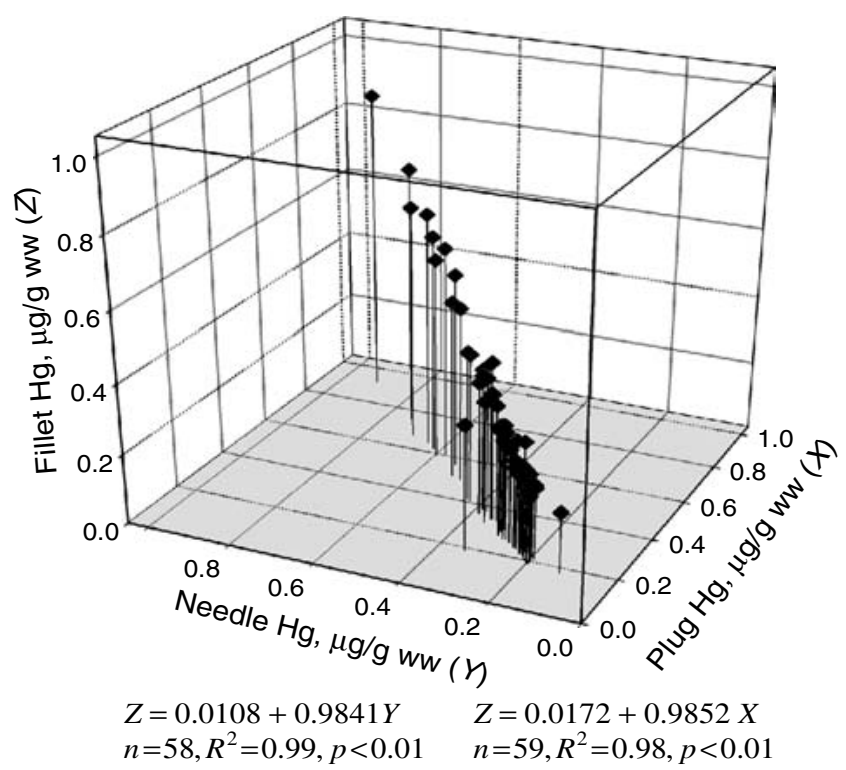

Fig. 3. Wet-weight $\mathrm{Hg}$ concentrations in plug $(X)$, needle $(Y)$, and fillet $(Z)$ samples from the same fish. Also shown are the linear regressions relating concentrations in the three sample types

\section{Additional Regression Analyses}

Concentrations of $\mathrm{Hg}$ in muscle and blood were highly correlated. The relationship for all fish from all sites was well described by a single log-log linear regression that was statistically significant $(p<0.01)$, explained $92 \%$ of the variation in fillet $\mathrm{Hg}$, and was similar between genders (Fig. 4). The model was accurate and reasonably precise (Fig. 4); averaged over all fish $(n=62)$, predicted fillet $\mathrm{Hg}$ concentrations differed from measured values by $18.6 \%, 40 \%$ differed by $<10 \%$, and $79 \%$ differed by $<25 \%$. However, one fish from site 6 with very low concentrations differed by $79 \%$ (Fig. 4; Table 5). Recomputation of the regression without this fish improved the fit (Table 5); the mean deviation was $13.8 \%, 46 \%$ of the measured values deviated by $<10 \%$, and $83 \%$ were $<25 \%$. The three fish from site 6 were within the general trend of the data, but they were well outside the concentration range of sites 1-5 (Fig. 4). Nevertheless, and although the fillet:blood regression computed without these fish was statistically significant $(p<0.01)$, it accounted for less variation $(82 \%)$ than the regressions computed for fish from all sites (Fig. 4).

Concentrations of $\mathrm{Hg}$ were also positively correlated with TL, weight, and age, but the three fish from site 6 differed substantially from the general trend of the relations (Fig. 5). The deviation was not as great for age, however (Fig. 5). Fish from sites 6 were therefore eliminated from some regression analyses involving TL and weight to determine the effect of these observations on the models. In addition, and despite overall positive correlations among $\mathrm{Hg}$, fish size, and age, inspection of the data and ANCOVA also indicated that the relations differed among sites (Fig. 5). Consequently, the overall correlations were relatively weak; although statistically significant $(p<0.01)$, simple linear regressions of TL, weight, and age accounted for $\leq 32 \%$ of the variation in fillet $\mathrm{Hg}$, even without the fish from site 6 in the TL and weight regressions (Fig. 5).

An ANCOVA model containing a common intercept and coefficients for TL, weight, and age together explained $37 \%$ of the variation in fillet $\mathrm{Hg}$ in fish from sites 1-5. All three variables contributed significantly $(p=0.01-0.08)$ even though they were intercorrelated. The model was accurate (i.e., unbiased) but not precise; measured fillet $\mathrm{Hg}$ concentrations differed by an average of $24.6 \%$ (maximum $=93.5 \%$ ) from the predicted values, and 24 of the 59 values (41\%) differed by $>25 \%$ (Fig. 6; Table 5). Of particular importance was that the pooled model underestimated four of the six highest concentrations from site 4 and one high value from each of sites 2 and 3 (Fig. 6). An alternative ANCOVA model with independent TL, weight, and age coefficients for each site was also significant $(p<0.01)$ and explained $65 \%$ of the variation in fillet Hg (Fig. 6; Table 5), about twice as much as the more general model with a single set of coefficients. Although accurate, this model was also not very precise (Fig. 6); the mean difference between the measured and predicted values was $18.6 \%$, seven values differed by $40-50 \%$, and one was 62\% (Fig. 6; Table 5). This model more accurately estimated the high concentrations in fish from site 4 but not those from sites 2 and 3 (Fig. 6).

Inclusion of TL, weight, and age improved both fillet:blood $\mathrm{Hg}$ regressions, but only slightly. For sites $1-5(n=58)$, a 
Table 5. Percent deviation (mean, minimum [Min], maximum [Max], and standard deviation [SD]) of fillet Hg concentrations in smallmouth bass relative to measured concentrations

\begin{tabular}{|c|c|c|c|c|c|c|c|}
\hline Surrogate variable(s) & $n$ & Mean & Min & Max & SD & $F_{d f}$ & $R^{2}$ \\
\hline Plug Hg, all samples ${ }^{a}$ & 59 & 4.1 & 0.0 & 47.3 & 6.2 & na & na \\
\hline Plug Hg, w/o max ${ }^{a, b}$ & 58 & 3.4 & 0.0 & 11.0 & 2.4 & na & na \\
\hline Needle $\mathrm{Hg}$, all samples ${ }^{\mathrm{a}, \mathrm{c}}$ & 58 & 3.6 & 0.1 & 30.4 & 4.6 & na & na \\
\hline Needle $\mathrm{Hg}$, w/o $\max ^{\mathrm{a}, \mathrm{b}, \mathrm{c}}$ & 57 & 3.1 & 0.1 & 16.3 & 3.0 & na & na \\
\hline Blood $\mathrm{Hg}^{\mathrm{d}}$, e & 62 & 15.2 & 0.6 & 72.3 & 12.9 & $671.57_{1}, 60^{* *}$ & 0.92 \\
\hline Blood $\mathrm{Hg}$ w/o max ${ }^{\mathrm{b}, \mathrm{d}, \mathrm{e}}$ & 61 & 13.8 & 0.2 & 46.6 & 11.4 & $579.24_{1,59} * *$ & 0.91 \\
\hline Blood $\mathrm{Hg}^{\text {a, d }}$ & 59 & 12.9 & 0.2 & 43.7 & 11.2 & $262.87_{1,57 *}^{* *}$ & 0.82 \\
\hline $\mathrm{TL}, \mathrm{Wt}$, Age $(\text { sites combined })^{\mathrm{a}, \mathrm{d}, \mathrm{e}, \mathrm{f}}$ & 58 & 24.5 & 0.6 & 93.5 & 20.8 & $10.65_{3,55}^{* *}$ & 0.37 \\
\hline TL, Wt, Age (sites separate) $)^{a}, \mathrm{~d}, \mathrm{e}, \mathrm{f}$ & 58 & 18.6 & 0.4 & 62.1 & 14.3 & $5.3015,42^{* *}$ & 0.65 \\
\hline Blood Hg, TL, Wt, Age ${ }^{a, d, f}$ & 58 & 11.4 & 0.2 & 53.0 & 8.8 & $93.82_{4}, 53^{* *}$ & 0.88 \\
\hline Blood Hg, TL, Wt, Age ${ }^{\mathrm{d}, \mathrm{e}, \mathrm{f}}$ & 61 & 13.7 & 0.4 & 60.3 & 10.9 & $214.31_{4,56}^{*}$ & 0.94 \\
\hline
\end{tabular}

Note. For plug and needle samples, deviation represents the difference between the measured concentrations. For all other estimates, deviations represent differences between measured and predicted fillet concentrations based on linear regressions of the indicated surrogate variables (TL, total length; Wt, weight). Also shown are the overall $F$-values $(* * p<0.01)$ with degrees of freedom $(d f)$ and coefficient of determination $\left(R^{2}\right)$ for the regressions. na, not applicable:

${ }^{\text {a }}$ Sites $1-5$.

${ }^{\mathrm{b}}$ One outlier deleted.

${ }^{c}$ One needle sample lost during processing.

${ }^{\mathrm{d}} \mathrm{TL}$, weight, fillet $\mathrm{Hg}$, and blood $\mathrm{Hg} \log _{10}$-transformed.

e Sites $1-6$.

${ }^{\mathrm{f}}$ One fish from site 1 deleted due to regenerated scales.

model that included blood $\mathrm{Hg}$, TL, weight, and age was statistically significant $(p<0.01)$ and explained $88 \%$ of the variation in fillet $\mathrm{Hg}$, a $6 \%$ improvement over the blood $\mathrm{Hg}$ only model (Fig. 7). The mean deviation of the measured from the predicted values was $11.4 \%$, with a maximum of $53 \%$ (Table 5). The latter value $(53 \%)$ represented one fish from site 1; all other deviations were $<25 \%$ (Fig. 7), $86 \%$ were $<20 \%$, and $48 \%$ were $<10 \%$. All independent variables were significant $(0.01<p<0.03)$, with each contributing about equally. Less improvement resulted for all fish from all sites $(n=61)$. The combined model (blood $\mathrm{Hg}$, TL, weight, and age) was statistically significant $(p<0.01)$ and explained $94 \%$ of the variation in fillet $\mathrm{Hg}$, which is only a $2 \%$ improvement over the blood Hg-only model (Fig. 7). Nevertheless, all variables except TL were at least marginally significant $(0.01$ $<p<0.02$; TL $p=0.06$ ), but the proportion of the total variation explained by each was small $(<1 \%)$. Deviations of the measured from the predicted concentrations were greater for this model than for the combined model without site 6 . The deviations averaged $13.7 \%$, with a maximum of $60.3 \%$ (Table 5); $92 \%$ were $<25 \%, 75 \%$ were $<20 \%$, and $41 \%$ were $<10 \%$. The maximum $(60.3 \%)$ represented one of the lowconcentration fish from site 6 , but four other values representing fish from sites 1 (same fish as previous model; 49.1\%), 2, 3, and 5 also deviated by $>25 \%$ (Fig. 7).

\section{Discussion}

Based on current guidelines (USEPA 2000, 2004), fillet $\mathrm{Hg}$ concentrations in smallmouth bass of legal size (>305 mm TL) from sites 1-5 could warrant restricted consumption (Fig. 5), which is consistent with the current Missouri advisory (MDHSS 2006). Historically, the highest concentrations (up to $0.64 \mu \mathrm{g} / \mathrm{g} \mathrm{ww}$ ) in Missouri smallmouth bass were from the
Eleven Point and Current rivers (MDC, Columbia, MO; unpublished monitoring data). Concentrations at our sites on these rivers overlapped the range of MDC data, but our maxima were higher (up to $0.88 \mu \mathrm{g} / \mathrm{g} \mathrm{ww}$ ). However, many of the MDC values represented composite samples comprising fish of differing sizes, which are not directly comparable to our data for individual fish. Conversely, previously reported $\mathrm{Hg}$ concentrations in smallmouth bass from the Big River were lower than in the Current and Eleven Point rivers, which agrees with the lower concentrations in our samples from site 6 (Table 3). The concentrations in our fish therefore appear typical for Missouri smallmouth bass, but they are lower than those in smallmouth bass from some other areas of the United States (e.g., Brumbaugh et al. 2001; May et al. 2000; Mueller and Serdar 2002; Neumann and Ward 1999; Stafford and Haines 1997; USEPA 2001). Concentrations in most of our fish exceeded the nationwide mean of $0.34 \mu \mathrm{g} / \mathrm{g}$ ww for smallmouth bass (USEPA 2001), but none approached the maximum reported by the USEPA ( $>5 \mu \mathrm{g} / \mathrm{g} w \mathrm{w})$. Concentrations in Missouri smallmouth bass, which eat predominantly crayfish (Probst et al. 1984; Rabeni 1992; Whitledge and Rabeni 1997) are typically lower than those in more strictly piscivorous freshwater species such as largemouth bass, walleye (Sander vitreum), northern pike (Esox lucius), or chain pickerel (E. niger; e.g., Brumbaugh et al. 2001; Lake et al. 2006; Neumann and Ward 1999; Peterson et al. 2005; USEPA 2001). Nevertheless, based on our results and those of other studies (e.g., Baker et al. 2004; Cizdziel et al. 2002a, 2002b, 2003; Peterson et al. 2005), we have no reason to suspect that the methods we evaluated would not be suitable for use with other species or for smallmouth bass with higher $\mathrm{Hg}$ concentrations.

Each of the potentially nonlethal methods we evaluated has advantages and disadvantages. Both of the biopsy methods (needle and plug) are highly reliable; that is, a sample can usually be obtained from a catchable-sized fish. In addition, 

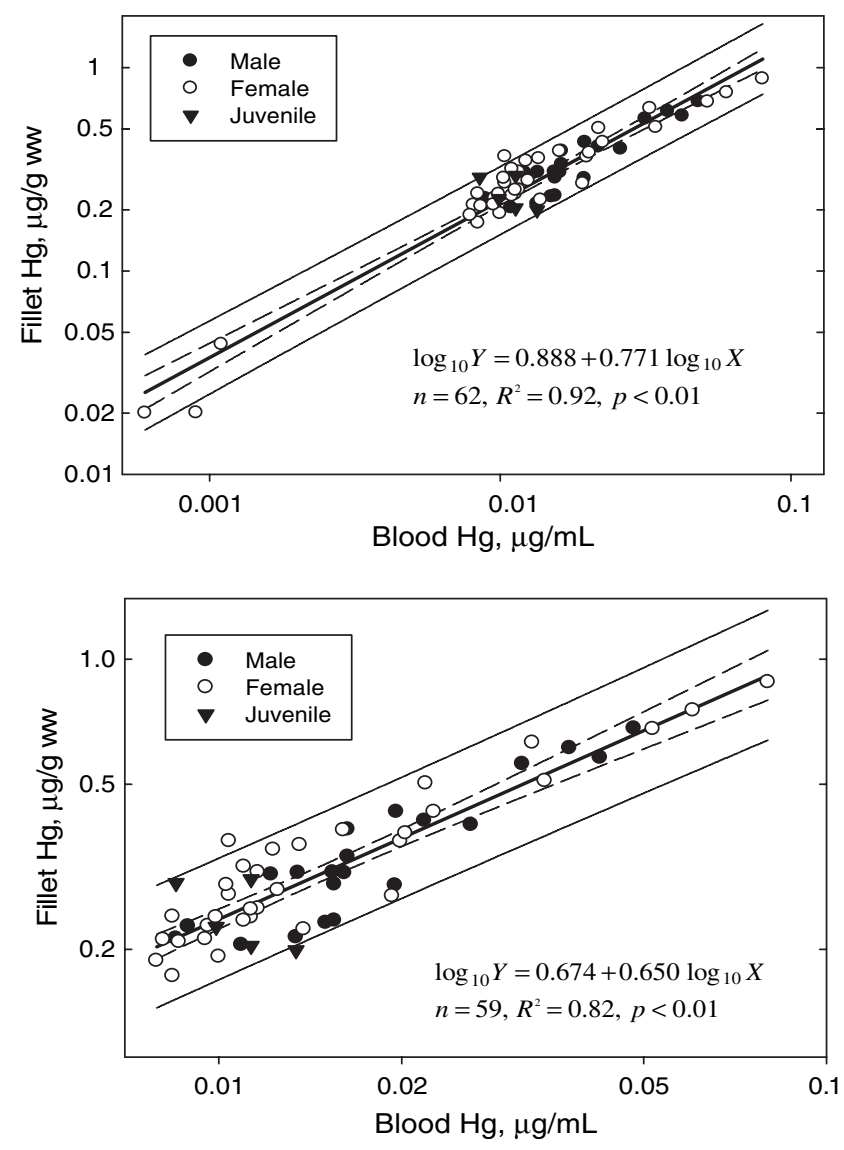

Fig. 4. Wet-weight fillet and blood concentrations of $\mathrm{Hg}$ in male, female, and juvenile smallmouth bass. Also shown are the linear regressions (heavy diagonal line) with 95\% confidence limits (dashed diagonal lines) and prediction regions (light solid diagonal lines). Upper panel: all data; points nearest the origin $(n=3)$ represent fish from site 6; lower panel: sites $1-5$ only

concentrations in needle and plug samples were nearly identical to those in fillets from the same fish. The three muscle methods also had virtually identical coefficients of variation (CVs) (means: 2.2-2.4\%; range: 1.8-4.0\%). Consequently, the choice between needle and plug sampling for smallmouth bass should be based on other factors. Our results were nearly identical to those of Peterson et al. (2005), who reported an $R^{2}$ of 0.96 for the relation between tissue plug and whole-body $\mathrm{Hg}$ concentrations in 210 fish of 13 species. However, Baker et al. (2004) reported slightly greater precision for biopsy punch than for needle samples obtained from northern pike and lake whitefish (Coregonus clupeaformis), which was attributed to the greater sample mass obtained with the punch. The muscle plugs obtained with a 7-mm-diameter biopsy punch also contained enough tissue mass (30-50 mg dw) to support replicate analyses, or analyses for other contaminants, and to determine moisture content. As noted by Baker et al. (2004), the loss of moisture from small-volume samples during freezer storage is an important potential source of variation. We applied the fillet moisture content, which was relatively constant, to our biopsy samples. Future studies would require a moisture determination for each sample or would have to rely on moisture values from other studies. Alternatively, the samples
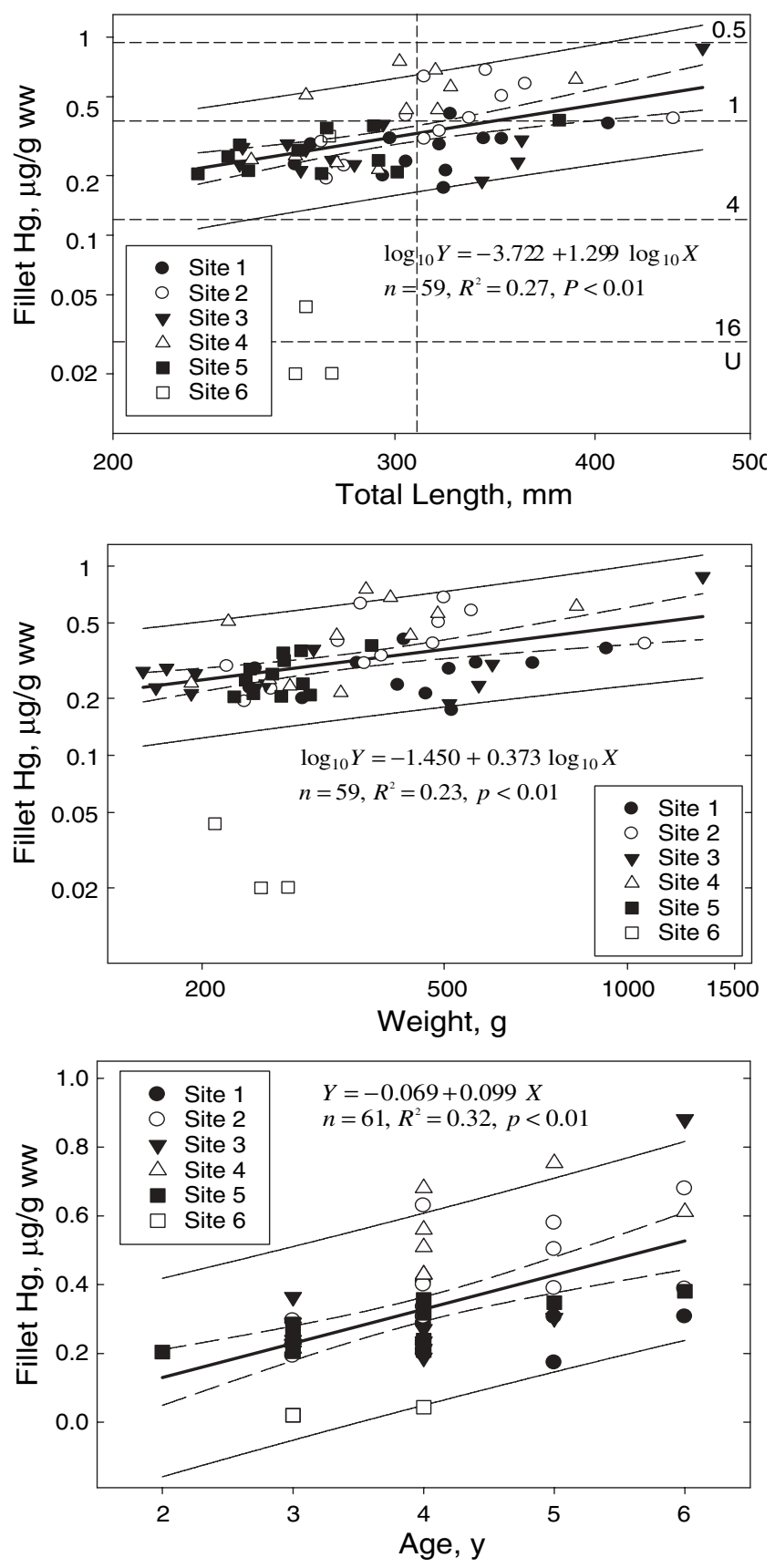

Fig. 5. Wet-weight fillet $\mathrm{Hg}$ concentrations and total length, weight, and age of smallmouth bass from sites 1-6. Also shown for sites 1-5 are the linear regression (heavy diagonal lines) with $95 \%$ confidence limits (dashed diagonal lines) and prediction region (light solid diagonal lines). The vertical reference line for TL indicates the minimum size for smallmouth bass in Missouri (12 in.; $305 \mathrm{~mm}$ ); horizontal reference lines and corresponding numbers represent the number of $8-\mathrm{oz}(0.227 \mathrm{~kg})$ meals $/$ month $(\mathrm{U}=$ unrestricted $)$ that could be consumed by $70-\mathrm{kg}$ humans from sensitive populations according to USEPA $(2000,2004)$ guidelines

could be analyzed wet by CA-AAS (e.g., Peterson et al. 2005), but precision is generally lower due to among-sample moisture differences and the samples would have to be analyzed soon after collection to avoid moisture loss; Peterson et al. (2002) 

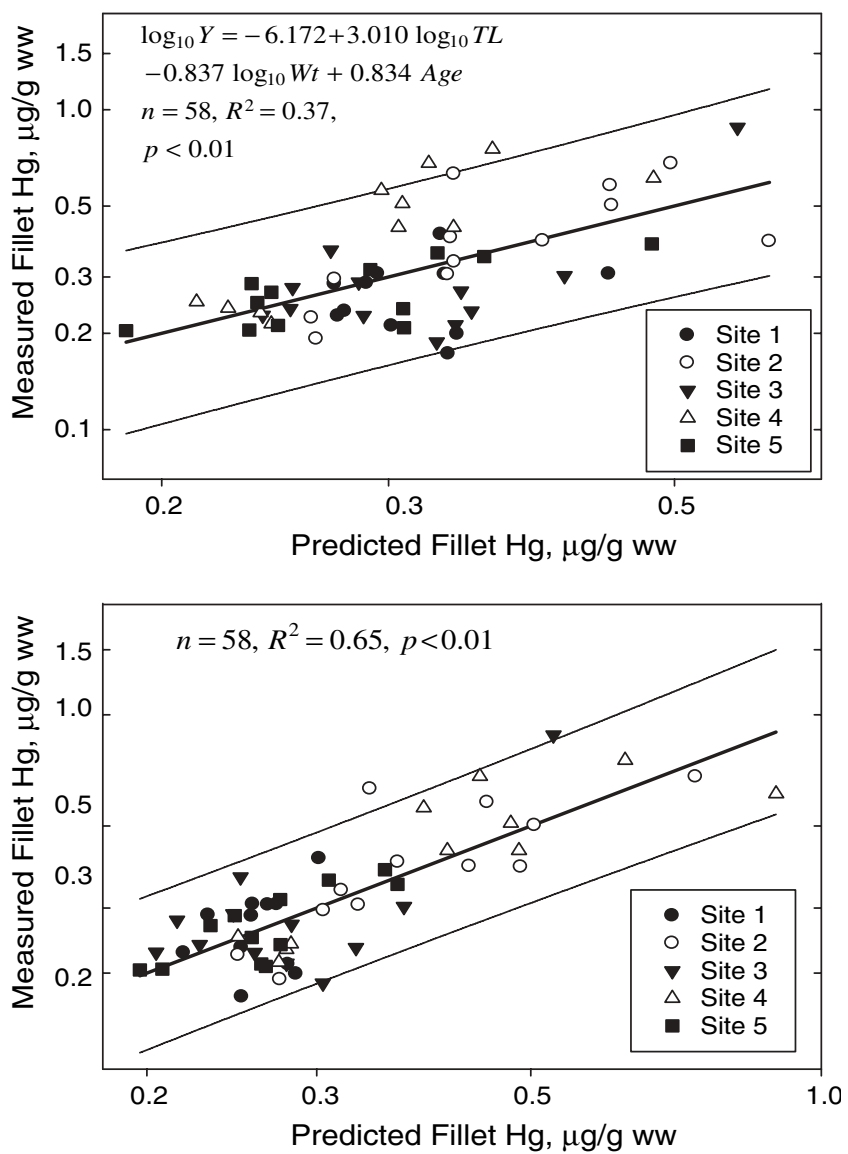

Fig. 6. Measured versus predicted wet-weight fillet $\mathrm{Hg}$ concentrations in smallmouth bass from sites 1-5. Upper panel: ANVOVA model that included a common intercept and coefficients for total length, fish weight, and age; lower panel: coefficients computed separately for each site. Shown for both are the line of equality $(Y=X)$ with $95 \%$ prediction region and, for the upper panel, regression parameters

demonstrated that plug samples can be stored for up to 100 days. Negative attributes of the biopsy punch include the generation of solid waste and the relatively large, visible wound it leaves, which would presumably be sealed prior to releasing the fish (Baker et al. 2004). In addition, although the punch is disposable, the other instruments require cleaning between fish to prevent cross-contamination.

The biopsy needle generates no solid waste, but in contrast to the findings of Baker et al. (2004), we found it more difficult to use, especially for sampling smaller fish. In addition, the expense of the instrument necessitates its use for multiple specimens and, consequently, thorough cleaning between fish. As also noted by Lake et al. (2006), the sample mass generated by each needle cut is small ( $\leq 10 \mathrm{mg} \mathrm{dw}$ ) and probably not sufficient for more than one $\mathrm{Hg}$ determination or analyses for other contaminants. Additional analyses would necessitate multiple needle cuts and wounds. Needle samples are also more susceptible to moisture loss due to their greater relative surface area (Lake et al. 2006), and accurately determining moisture content would be more difficult due to the smaller sample mass.
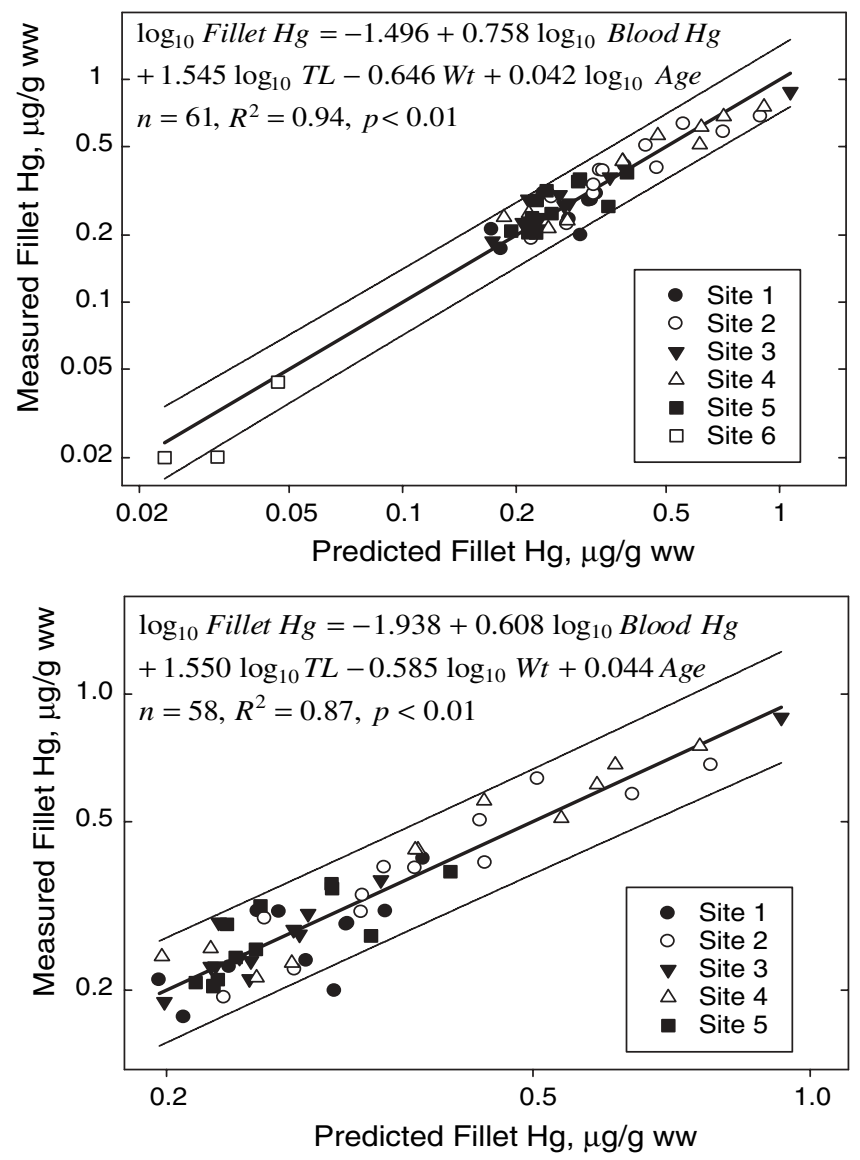

Fig. 7. Measured versus predicted wet-weight $\mathrm{Hg}$ concentrations in smallmouth bass based on multiple linear regression models that included blood $\mathrm{Hg}$ and a common intercept and coefficients for total length, fish weight, and age. Upper panel: all sites; lower panel: sites $1-5$. Shown for both are the line of equality $(Y=X), 95 \%$ prediction region, and regression parameters

Blood sampling with a needle and syringe was moderately difficult to perform. More importantly, the estimates it produced were not as precise as those from plug or needle sampling and the values are not directly comparable to muscle concentrations. We obtained $R^{2}$ values of $0.82-0.92$ for $\log -\log$ relations between blood $\mathrm{Hg}$ and fillet $\mathrm{Hg}$, which improved slightly to $0.88-0.94$ with the inclusion of TL, weight, and age into the regressions. These values are similar to the maximum $R^{2}$ of 0.89 for the relation between $\mathrm{Hg}$ in largemouth bass scales and fillets reported by Lake et al. (2006), but they greatly exceeded the $R^{2}$ values for relations between blood and fillet $\mathrm{Hg}$ in the five species investigated by Cizdziel et al. (2003). Moreover, Lake et al. (2006) were not able to improve the fit of their models by incorporating fish size. They also noted that least squares regression accounts only for error in the dependent variable (i.e., fillet $\mathrm{Hg}$ ) and assumes that the independent variables (blood or scale $\mathrm{Hg}$, TL, weight, age) are measured without error, which is not true. Lake et al. (2006) reported the $\mathrm{CV}$ (= RSD) for $\mathrm{Hg}$ in replicate scale samples as 7.4\% and $\mathrm{Hg}$ concentrations in scales that were about sevenfold greater than our concentrations in blood. The CV of the biopsy samples analyzed by Baker et al. (2004) was $9.2 \%$. 
Lake et al. (2006) therefore concluded that the $95 \%$ confidence region of predicted fillet concentrations was too wide to be useful after accounting for error in both the fillet and biopsy measurements. Our replicates were less variable; RSDs for all of our analyses averaged $2.3 \%$, an amount of variation we think can be ignored in practical applications, especially in screening-level assessments. In addition, and in contrast to small-mass muscle samples, blood samples of $\leq 1 \mathrm{~mL}$ can be analyzed for other contaminants (e.g., Brumbaugh et al. 2005).

There are other aspects of blood sampling that are not shared by the muscle-based biopsy methods that should be considered. As was true in the five species investigated by Cizdziel et al. (2003), concentrations of $\mathrm{Hg}$ in smallmouth bass blood were substantially lower than in muscle. Our lowest blood $\mathrm{Hg}$ concentrations were near the LOD $(0.0006 \mu \mathrm{g} / \mathrm{mL}$ ww); however, concentrations were well above the LOD in blood from legal-sized fish in which fillet concentrations were sufficiently high to warrant potential concern based on current guidelines (USEPA 2000, 2004; Fig. 5). Nevertheless, Hg concentration might be too low to measure accurately in extremely small volumes (i.e., $\leq 0.1 \mathrm{~mL}$ ) of blood from smaller fish or from fish from locations where $\mathrm{Hg}$ concentrations are lower. An additional consideration is anticoagulants, which are often employed to inhibit clotting. The sodium heparin we used contained a miniscule amount of $\mathrm{Hg}$ that could be discounted, but this might not hold true for all batches of heparin or for other anticoagulants. Anticoagulant might not be necessary for small blood volumes handled quickly, however. Blood sampling with disposable needles and syringes also generates solid waste that must be rendered unusable prior to disposal, but there is nothing to clean between fish.

Yet another consideration is seasonal variability. Concentrations of $\mathrm{Hg}$ in fish might vary seasonally in response to the reproductive cycle, diet, and other factors (Cizdziel et al. 2002b, 2003; Ward and Neumann 1999). As noted by Cizdziel et al. (2003), blood is the conduit through which $\mathrm{Hg}$ accumulated from the diet is transported to the liver and muscles for storage, and blood $\mathrm{Hg}$ concentrations can increase relative to muscle during periods of fasting. However, and in contrast to some other chemical contaminants, maternal transfer of $\mathrm{Hg}$ is of relatively little significance to the total $\mathrm{Hg}$ burden of the fish (Wiener et al. 2002). Nevertheless, changes in $\mathrm{Hg}$ distribution might be induced indirectly by seasonal feeding differences as well as by changing temperatures, activity and feeding patterns, and migration. Although concentrations in muscle would also vary (Cizdziel et al. 2003), we would not expect the relation between muscle sample types to differ.

The long-term effects of blood and biopsy sampling on smallmouth bass have not been evaluated. Nevertheless, previous studies indicated no long-term effects associated with any of the methods we evaluated. The collection of small volumes of blood from fish via needle and syringe is a routine practice that generally results in only short-term effects (Blaxhall and Daisley 1973; Bracewell et al. 2004; Braley and Anderson 1992; Breazile et al. 1982; McCarthy et al. 1973), and repeated sampling is possible (Braley and Anderson 1992; Hoffmann and Lommel 1984). Evidence from the scientific literature also indicates a good probability of survival following biopsy sampling (e.g., Baker et al. 2004). However, we also note that there are many alternative instruments and procedures that could be evaluated in an attempt to further reduce the effects on the fish and optimize the procedures. Biopsy instruments are available in a variety of sizes and configurations. Instruments other than the ones we chose, which were selected because they had been used successfully in previous studies, could provide the necessary tissue mass with less stress to the fish. Stress on the fish might also be reduced by incorporating anesthesia, wound disinfection, and suturing or sealing of the wound after sampling (e.g., Baker et al. 2004). These latter aspects, which were beyond the scope of our study, should be investigated and optimized in future studies.

Previous studies of smallmouth bass demonstrated increasing $\mathrm{Hg}$ concentrations with size, age, or both (May et al. 2000; Neumann and Ward 1999; Stafford and Haines 1997). However, and contrary to expectations, concentrations in our fish were poorly correlated with fish size and age. By themselves, fish size and age had little predictive capacity, the size- and age-adjusted fillet $\mathrm{Hg}$ concentrations were nearly as variable as the unadjusted values, and accounting for size and age had little effect on the predictive capability of the surrogate measures. Moreover, and despite the facts that the sites are in close proximity to each other and that four are hydrologically connected (Fig. 1), the relations between $\mathrm{Hg}$ and fish size and age differed among the sites. Many factors could have contributed to this variation, including differing $\mathrm{Hg}$ loading rates, food habits, methylation efficiency, fish movements, and bioenergetic variables such as growth rate, water temperature, and food conversion efficiency (e.g., Brumbaugh et al. 2001; Cabana et al. 1994; Stafford and Haines 2001; Ulrich et al. 2001; Whitledge et al. 2003). These represent additional subjects for further investigation.

\section{Summary and Conclusions}

Any of the methods we evaluated could be used in lieu of fillet sampling to determine $\mathrm{Hg}$ concentrations in smallmouth bass. Each has distinct advantages and disadvantages. Of the three, we would prefer the biopsy punch because of its ease of use, reliability, direct translation to fillet concentrations, and the comparatively large sample mass it yields. However, we also note that the successful application of any of these methods depends on the protocols in which they are employed because the small samples are potentially vulnerable to contamination from a variety of sources at all stages of processing and analysis. Future studies should seek to minimize effects on the fish and investigate possible reasons for the differing $\mathrm{Hg}$ concentrations and fish size: $\mathrm{Hg}$ relations among otherwise similar Missouri streams.

Acknowledgments. This study was supported by the Park-Oriented Biological Support project, a partnership between the USGS Inventory and Monitoring Program and the NPS, and by the USGS Contaminants Biology Program. Fish were collected under the supervision of J. Ackerson, D. Mayer, R. Legler, and M. Reed (MDC). M. McKee (MDC) coordinated the collections and provided unpublished MDC monitoring data. V. Grant, M. Gossett, J. Luraas, and E. Kunz (all NPS), and M. Mac, J. Besser, B. Poulton, and S. Olson (all USGSCERC) assisted in the field. T. May, J. Arms, S. Koppi, and V. Melton (all USGS-CERC) assisted in the laboratory. Scales were prepared 
and read by W. Simpson and D. Noltie (University of MissouriColumbia) and by J. Dekoske (MDC). T. May, M. Brigham, and D. Tillitt (all USGS) reviewed earlier versions of the paper.

\section{References}

ASIH, AFS, AIFRB (2004) Guidelines for use of fishes in field research. American Fisheries Society, Bethesda, MD. Available from http://www.fisheries.org/html/Public_Affairs/Sound_Science/Guidelines2004.shtml)

Baker RF, Blanchfield JP, Paterson MJ, Flet RJ, Wesson L (2004) Evaluation of nonlethal methods for the analysis of mercury in fish tissue. Trans Am Fish Soc 133:568-576

Blaxhall PC, Daisley KW (1973) Routine hematological methods for use with fish. J Fish Biol 5:771-781

Bracewell P, Cowx IG, Uglow RF (2004) Effects of handling and electrofishing on plasma glucose and whole blood lactate of Leuciscus cephalatus. J Fish Biol 64:65-71

Braley H, Anderson TA (1992) Changes in the blood metabolite concentrations in response to repeated capture, anesthesia, and blood sampling in the golden perch, Macquaria ambigua. Comp Biochem Physiol 103A:445-450

Breazile JE, Zinn LL, Yauk JC, Mass HJ, Wollscheid. J (1982) A study of haematological profiles of channel catfish, Ictalurus punctatus (Rafinesque). J Fish Biol 21:305-309

Brumbaugh WG, Krabbenhoft DP, Helsel DR, Wiener JG, Echols KR (2001) A national pilot study of mercury contamination of aquatic ecosystems along multiple gradients: bioaccumulation in fish. Biological Sciences Report USGS/BRD/BSR-2001-0009. US Geological Survey, Reston, VA

Brumbaugh WG, Schmitt CJ, May TW (2005) Concentrations of cadmium, lead, and zinc in fish from mining-influenced waters of Northeastern Oklahoma: sampling of blood, carcass, and liver for aquatic biomonitoring. Arch Environ Contam Toxicol 49:76-88

Cabana G, Tremblay A, Kalff J, Rasmussen JB (1994) Pelagic food chain structure in Ontario lakes: a determinant of mercury levels in lake trout (Salvelinus namaycush). Can J Fish Aquat Sci 51:381-389

Cizdziel J, Hinners T, Cross C, Pollard J (2003) Distribution of mercury in the tissues of five species of freshwater fish from Lake Mead, USA. J Environ Monit 5:802-807

Cizdziel JV, Hinners TA, Heithmar EM (2002a) Determination of total mercury in fish tissues using combustion atomic absorption spectrometry with gold amalgamation. Water Air Soil Pollut 135:355-370

Cizdziel JV, Hinners TA, Pollard JE, Heitmar EM, Cross CL (2002b) Mercury concentrations in fish from Lake Mead, USA, related to fish size, condition, trophic level, location, and consumption risk. Arch Environ Contam Toxicol 43:309-317

Crawford BA, Leider SA, Tipping JM (1977) Technique for rapidly taking samples of skeletal muscle from live adult steelhead trout. Prog Fish-Cult 39:125

Franson JC, Schmutz JA, Creekmore LH, Fowler CA (1999) Concentrations of selenium, mercury, and lead in blood of emperor geese in western Alaska. Environ Toxicol Chem 18:965-969

Gale N, Adams CD, Wixson BF, Loftin KA, Huang Y-W (2004) Lead, zinc, copper, and cadmium in fish from and sediments from the Big River and Flat River Creek of Missouri's Old Lead Belt. Environ Geochem Health 26:37-49

Gremillion PT, Cizdziel JV, Cody NR (2005) Caudal fin mercury as a non-lethal predictor of fish-muscle mercury. Environ Chem 2:9699

Hamilton SJ, Holley KM, Buhl KJ, Bullard FA, Weston LK, McDonald SF (2004) Evaluation of flushing of a high-selenium backwater channel in the Colorado River. Environ Toxicol 19:5181

Hightower JM, Moore D (2003) Mercury levels in high-end consumers of fish. Environ Health Perspect 111:604-608

Hoffman R, Lommel R (1984) Effects of repeated blood sampling on some blood parameters in freshwater fish. J Fish Biol 24:245-251

Jearld A Jr (1983) Age determination. In: Nielsen LA, Johnson DL (eds) Fisheries techniques. American Fisheries Society, Bethesda, MD, pp 301-324

Lake JL, Ryba SA, Servst JR, Libby AD (2006) Mercury in fish scales as an assessment method for predicting muscle tissue mercury concentrations in largemouth bass. Arch Environ Contam Toxicol 50:539-544

Leitner JK, Isely JJ (1994) A liver and muscle biopsy technique for electrophoretic evaluation of largemouth bass. Prog Fish-Cult 56:288-290

May JT, Hothem RL, Alpers CN, Law MA (2000) Mercury bioaccumulation in fish in a region affected by historic gold mining: the South Yuba River, Deer Creek, and Bear River watersheds, California, 1999. Open-File Report 00-367. US Geological Survey, Sacramento, CA

McCarthy DH, Stevenson JP, Roberts MS (1973) Some blood parameters of the rainbow trout (Salmo gairdneri Richardson). I. The Kamloops variety. J Fish Biol 5:1-8

Menau KJ (1997) Big River watershed inventory and assessment. Missouri Department of Conservation, Cape Girardeau, MO (viewed online 07/31/2006 at http://mdc.mo.gov/fish/watershed/ big/contents/20cotxt.htm; last modified 11/08/2001)

Miller SM, Wilkerson TF Jr (2000) Eleven Point River watershed inventory and assessment. Missouri Department of Conservation, West Plains, MO (viewed online 04/05/2006 at http://mdc.mo.gov/fish/watershed/elevenpt/contents/090ctxt.htm; last modified $02 / 01 / 2001)$

MDC (Missouri Department of Conservation) (2006) Missouri species and communities of conservation concern checklist Natural Heritage Program, Jefferson City, MO

MDHSS (Missouri Department of Health and Senior Services) (2006) 2006 Fish advisory. A guide to eating fish in Missouri. Jefferson City, MO. Available from http://www.dhss.state.mo.us/NewsAndPublicNotices/05FishAdvisory.pdf

Mueller KW, Serdar DM (2002) Total mercury concentrations among fish and crayfish inhabiting different trophic levels in Lake Whatcom, Washington. J Freshwater Ecol 17:621-633

Neumann RM, Ward SM (1999) Bioaccumulation and biomagnification of mercury in two warmwater fish communities. J Freshwater Ecol 14:487-497

Peles JD, Glenn TC, Brant HA, Wall AK, Jagoe CH (2006) Mercury concentrations in largemouth bass (Micropterus salmoides) from five South Carolina reservoirs. Water Air Soil Pollut 173:151162

Petersen JC, Adamski MC, Bell RW, Davis JV, Femmer SR, Freiwald DA, Joseph RL (1998) Water quality in the Ozark plateus, Arkansas, Kansas, Missouri, and Oklahoma, 1992-95. Circular 1158. US Geological Survey, Reston, VA

Peterson SA, Herlihy AT, Hughes RM, Motter KL, Robbins JM (2002) Level and extent of mercury contamination in Oregon, USA, lotic fish. Environ Toxicol Chem 21:2157-2164

Peterson SA, Van Sickle J, Hughes RM, Schacher JA, Echols SF (2005) A biopsy procedure for determining filet and predicting whole-fish mercury concentration. Arch Environ Contam Toxicol 48:99-107

Probst WE, Rabeni CF, Covington WG, Marteney RE (1984) Resource use by stream-dwelling rock bass and smallmouth bass. Trans Am Fish Soc 113:283-294

Rabeni CF (1992) Trophic linkage between stream centrarchids and their crayfish prey. Can J Fish Aquat Sci 49:1714-1721 
Schmitt CJ, Blazer VS, Dethloff G, Tillitt DE, Gross TS, DeWeese LR, Smith SB, Goede RW, Bartish TA, Kubiak TJ (1999) Biomonitoring of Environmental Status and Trends (BEST) Program: Field procedures for assessing the exposure of fish to environmental contaminants. Biological Resources Division, Information and Technology Report USGS/BRD-1999-0007. US Geological Survey, Columbia, MO

Schmitt CJ, Finger SE (1987) The effects of sample preparation on the measured concentrations of eight elements in the edible tissues of fish contaminated by lead mining. Arch Environ Contam Toxicol 16:185-207

Stafford CP, Haines TA (1997) Mercury concentrations in Maine sport fishes. Trans Am Fish Soc 126:144-152

Stafford CP, Haines TA (2001) Mercury concentration and growth rate in two piscivore populations. Environ Toxicol Chem 20:2099-2101

Ullrich SM, Tanton TW, Abdrahitova SA (2001) Mercury in the aquatic environment: a review of factors affecting methylation. Crit Rev Environ Sci Technol 31:241-293

USEPA (US Environmental Protection Agency) (2000) Guidelines for assessing chemical contaminant data for use in fish consumption advisories. Volume 2: Risk assessment and fish consumption limits, 3rd ed. EPA-823-B-00-008. US Environmental Protection Agency, Office of Water, Washington, DC

USEPA (US Environmental Protection Agency) (2001) Mercury update: impact on fish advisories. EPA-823-F01-011. US Environmental Protection Agency, Office of Water, Washington, DC
USEPA (US Environmental Protection Agency) (2004) Origin of the $1 \mathrm{meal} /$ week noncommercial fish consumption rate in national advisory for mercury. Technical Memorandum, March 11, 2004. Office of Water, National Fish and Wildlife Contamination Program, Washington, DC. Available from http://www.epa.gov/ waterscience/fishadvice/advice.html

Uthe JF (1971) A simple field technique for obtaining small samples of muscle from living fish. J Fish Res Bd Can 28:12031204

Waddell B, May T (1995) Selenium concentrations in the razorback sucker (Xyrauchen texanus): substitution of non-lethal muscle plugs for muscle tissue in contaminant assessment. Arch Environ Contam Toxicol 28:321-326

Ward SM, Neumann RM (1999) Seasonal variations in concentrations of mercury in axial muscle tissue of largemouth bass. North Am J Fish Mgmt 19:89-96

Whitledge G, Hayward RS, Zweifel RD, Rabeni CF (2003) Development and laboratory evaluation of a bioenergetic model for subadult and adult smallmouth bass. Trans Am Fish Soc 132:316325

Whitledge G, Rabeni C (1997) Energy sources and ecological role of crayfishes in an Ozark stream: insights from stable isotope and gut analyses. Can J Fish Aquat Sci 54:2555-2563

Wiener JG, Krabbenhoft DP, Heinz GH, Scheuhammer AM (2002) Ecotoxicology of mercury. In: Hoffman DJ, Rattner BA, Burton GA Jr, Cairns J Jr (eds) Handbook of ecotoxicology. 2 ed. Lewis Publishers, Boca Raton, FL, pp 409-463 